Research article

\title{
Two new marine species of Cocconeis (Bacillariophyceae) from the west coast of Sweden
}

\author{
Adil Y. AL-HANDAL ${ }^{1, *}$, Catherine RIAUX-GOBIN ${ }^{2}$, Regine JAHN ${ }^{3}$, \\ Angela Katarina WULFF ${ }^{4} \&$ Alison MINEROVIC ${ }^{5}$ \\ ${ }^{1,4}$ Department of Biological and Environmental Sciences, University of Gothenburg, \\ Göteborg, Sweden. \\ ${ }^{2}$ LABEX “CORAIL”, PSL USR 3278 CNRS-EPHE, CRIOBE-Université de Perpignan, \\ FR-66860, France. \\ ${ }^{3}$ Botanischer Garten und Botanisches Museum Berlin-Dahlem, \\ Freie Universität Berlin, Germany. \\ ${ }^{5}$ The Academy of Natural Sciences of Drexel University, Philadelphia, PA 19103, USA. \\ *Corresponding author: adil.yousif@bioenv.gu.se \\ ${ }^{2}$ Email: catherine.gobin@univ-perp.fr \\ ${ }^{3}$ Email: r.jahn@bgbm.org \\ ${ }^{4}$ Email: angela.wulff@bioenv.gu.se \\ ${ }^{5}$ Email: ans_diatomherbarium@drexel.edu
}

\begin{abstract}
This paper is part of a project of studying benthic diatom biodiversity on marine coastal regions of Sweden with focus on rare and less known species. Two new species of Cocconeis Ehrenb. are described from Vrångö, a small island in the west coast of Sweden. Both species were found as epiphytic on the green alga Ulva intestinalis L. Cocconeis magnoareolata Al-Handal, Riaux-Gob., R.Jahn \& A.K.Wulff sp. nov. is a small species not exceeding $9 \mu \mathrm{m}$ in length and characterized by having large subquadrangular areolae on the sternum valve. Cocconeis vrangoensis Al-Handal \& RiauxGob. sp. nov. appears similar to some taxa of the 'Cocconeis scutellum complex', but differs by its stria density on both valves and variable features of the areola and valvocopula ultrastructure. Detailed descriptions based on light and electron microscopy examination, a comparison with closely related taxa, as well as a description of the habitat of both species are here presented.
\end{abstract}

Keywords. Cocconeis, diatoms, epiphytes, marine, new species, Sweden.

Al-Handal A.Y., Riaux-Gobin C., Jahn R., Wulf A. \& Minerovic A. 2019. Two new marine species of Cocconeis (Bacillariophyceae) from the west coast of Sweden. European Journal of Taxonomy 497: 1-16. https://doi.org/10.5852/ejt.2019.497

\section{Introduction}

Cocconeis Ehrenb. is one of the most diversified genera of diatoms in terms of number of species and variability of habitats. It is found in all types of aquatic habitats from freshwater to sea water, from the tropics to the polar regions, with a wide variability in valve ultrastructure (Riaux-Gobin 1991; 
Riaux-Gobin \& Compère 1996; Romero \& Navarro 1999; De Stefano et al. 2000; Suzuki et al. 2001; Riaux-Gobin et al. 2015). Although some taxa are found in the plankton (Sar et al. 2003), the majority of the species of Cocconeis are epiphytic, attached by its raphe valve to various types of macroalgae (De Stefano et al. 2008). New species of Cocconeis are always being described and the number of species given by VanLandingham (1979) (320 species) has increased remarkably during the last three decades. According to Guiry \& Guiry (2018), 812 species and intraspecific taxa of Cocconeis have been published, although several have not been validated.

Morphological similarities between numerous closely related taxa of Cocconeis have led to uncertainties in the identification of many species. Because of this, several works attempted to typify such species by examining fine structure of type material and compare it with recent specimens examined under electron microscopy (e.g., De Stefano et al. 2008; Jahn et al. 2009). One of such problematic species is C. scutellum Ehrenb., with ca 15 varieties being separated on the basis of the fine structure of the areolae and valvocopulae (De Stefano et al. 2008). Such distinction between several varieties is important in the context of biodiversity, but it seems rather unhelpful in ecological surveys where morphological features may not appear different using light microscopy.

The present work describes C. magnoareolata Al-Handal, Riaux-Gob., R.Jahn \& A.K.Wulff sp. nov. and C. vrangoensis Al-Handal \& Riaux-Gob. sp. nov. as two new marine species, using light microscopy and scanning electron microscopy. Both species were found as epiphytic on the chlorophyte Ulva intestinalis L. These two new species may, under light microscopy, look like members of the 'Cocconeis scutellum complex', but their ultrastructure appear different.

\section{Material and methods}

Samples were collected from the eastern side of Vrångö Island $\left(57^{\circ} 34^{\prime} \mathrm{N}, 11^{\circ} 47^{\prime} \mathrm{E}\right)$, in the strait of Kattegat on the west coast of Sweden (Fig. 1). Vrångö Island is part of the archipelago of Kattegat which, together with Skagerrak strait, connect the Baltic Sea with the North Sea. Thalli of the chlorophyte Ulva intestinalis were collected from the intertidal zone and kept in a plastic container filled with water from the same locality to which $10 \mathrm{ml}$ of glutaraldehyde were added for preservation. In the laboratory, samples were vigorously shaken to remove diatom frustules. The suspension containing diatoms was first washed with deionized water by filtration and then boiled in 30\% hydrogen peroxide for 20 min. Few milliliters of $50 \%$ hydrochloric acid were added to remove the carbonates. After several rinses with deionized water, one milliliter of the cleaned diatom suspension was left to dry on a cover slip and then mounted in Naphrax ${ }^{\circledR}$. Light microscopy images were taken using a Zeiss Axioimager 2 microscope with differential interference contrast objectives at the Botanisches Museum, Berlin. Scanning electron microscopy images were taken using Hitachi S-4500 SEM operated at $5 \mathrm{kv}$ in Perpignan University, France, and a Hitachi S-4500 SEM in Botanisches Museum, Berlin, Germany.

\section{Abbreviations}

$\mathrm{RV} \quad=\quad$ raphe valve

$\mathrm{SV} \quad=\quad$ sternum valve

$\mathrm{LM}=$ light microscopy

SEM = scanning electron microscopy

\section{Results}

Ulva intestinalis is a widely distributed macrophyte on all the coasts of Sweden, from the brackish water of the Baltic to the marine water on the west coast (Leskinen et al. 2004). The exam of the epiphytic diatoms on this macrophyte revealed a number of species in varying occurrence and densities. The most abundant species, which covered most of the thallus, was Striatella unipunctata (Lyngb.) 
C.Agardh. Several taxa of Cocconeis were observed in moderate densities such as C. scutellum Ehrenb., C. stauroneiformis (W.Sm.) Okuno, C. magnoareolata sp. nov., and C. vrangoensis sp. nov. Some other rare taxa, including species of the genera Mastogloia Thwaites ex W.Sm. and Fragilaria Lyngbye, as well as several other unidentified species were present. Salinity of the surface water in the Kattegat varies between 25 and $30 \mathrm{psu}$, being affected by water discharge from rivers and by water masses coming from the Baltic Sea (Kristiansen \& Eyvind 2015).

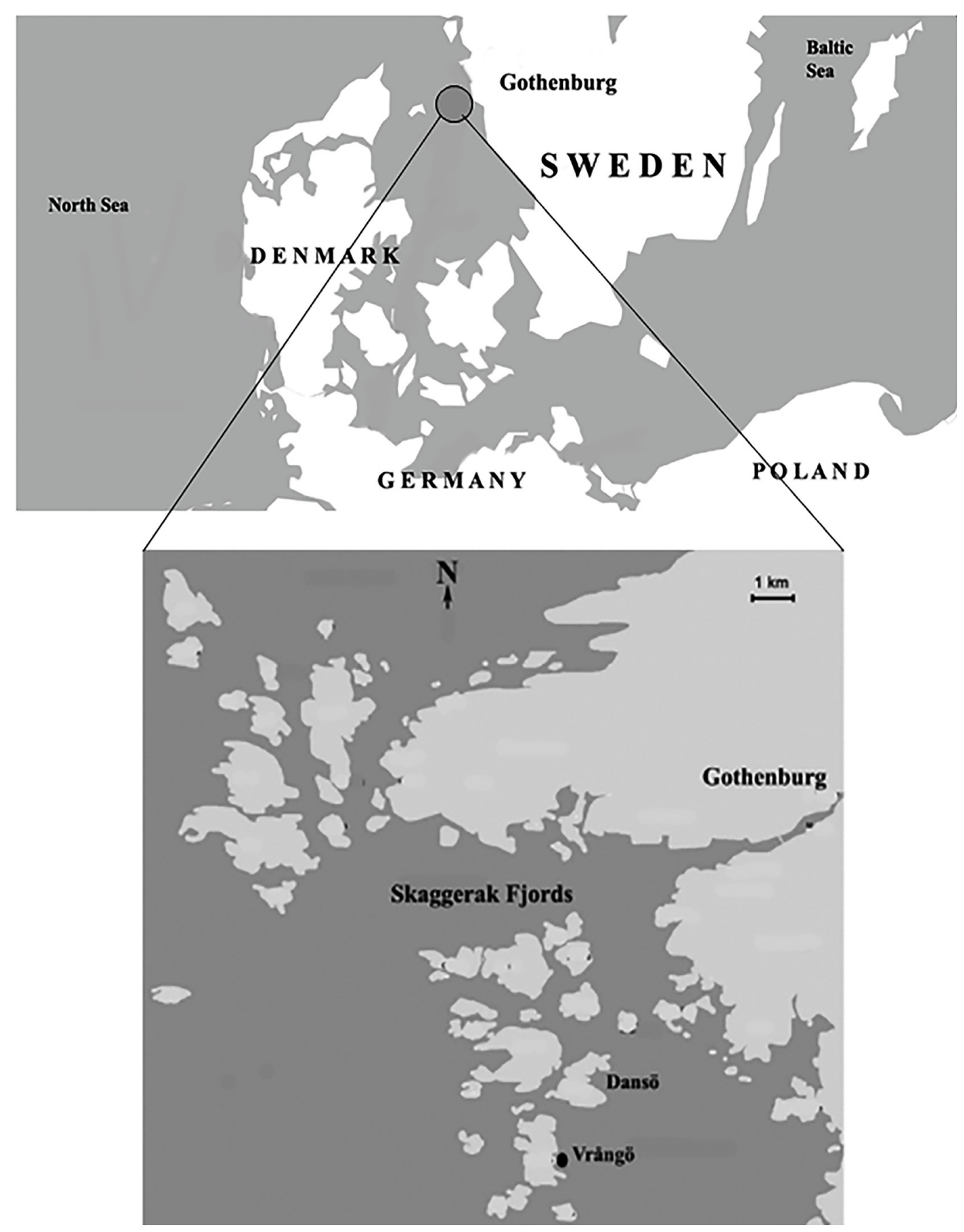

Fig. 1. Map of the west coast of Sweden and location of sampling site, Vrångö Island (black circle). 
Both new species were found as epiphytic on Ulva intestinalis which were common in marine water pools between rocks at the high tide level. These species were not found on other macroalgae, including brown and red algae, collected from the same site, nor from the sediment in the Vrångö Island location. Cocconeis magnoareolata sp. nov. was rare, while $C$. vrangoensis sp. nov. was rather frequent.

\author{
Class Bacillariophyceae Haeckel \\ Order Achnanthales P.C.Silva \\ Family Coccconeidaceae Kütz. \\ Genus Cocconeis Ehrenb.
}

Cocconeis magnoareolata Al-Handal, Riaux-Gob., R.Jahn \& A.K.Wulff sp. nov.

Figs 2-7, 16-27

\title{
Differential diagnosis (LM)
}

Valves elliptic to broadly elliptic with rounded apices. Apical axis 6-8.5 $\mu \mathrm{m}(7 \pm 0.8)$, transapical axis 4.5-6 $\mu \mathrm{m}(4.8 \pm 0.5, \mathrm{n}=60)$. Raphe filiform and straight, axial area very narrow, RV central area very small. Striae coarse on both valves, weakly radiate to parallel at the middle and strongly radiate near the apices, $21-22$ in $10 \mu \mathrm{m}$ on both valves. Areolae subquadrangular, coarse and distinct, 4-5 in each stria at the middle of the valve.

\section{Etymology}

The epithet given to the species refers to the large shape of the areolae on both valves.

\section{Type material}

Holotype (Figs 2, 6: http://phycobank.org/1000794)

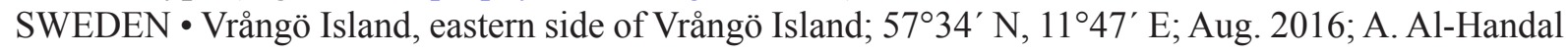
s.n. leg.; intertidal zone, as epiphytic on Ulva intestinalis; BGBM, slide B 400043104.

\section{Isotype}

SWEDEN - Same data as for the holotype; Department of Biological and Environmental Sciences, University of Gothenburg, slide V001.

\section{Description (SEM)}

\section{Sternum valve}

Externally, flat to weakly convex with short mantle (Figs 17-18). Axial area narrow and straight, reaching valve apices (Fig. 17). Striae uniseriate, reaching valve margin, weakly radiate at the middle and curved on apices. Areolae large, subquandragular with round corners, becoming slightly oblong on the apices (Figs 17-18). Areolae occluded by reticular hymenes with short slits arranged on the margin of the areolae (Fig. 19, arrow). Internally, virgae strongly silicified and more prominent than on the external face, sternum relatively large and straight, ending by a triangular hyaline area on apices (Fig. 16). Areolae more oblong than on the external side but the last areolae near valve margin are round (Fig. 16). SV valvocopula open, fimbriae short and triangle-like (Figs 20-21).

\section{Raphe valve}

Externally, valve face flat with a shallow mantle (Figs 25-26). Raphe straight, filiform, proximal raphe endings indistinct (Figs 22, 26), terminal raphe fissures round and slightly widening, helictoglossae very low. Axial area very narrow, central area small and round. Striae uniseriate, weakly radiate at the middle and curved on apices. Areolae coarse, increase in size from the axial area towards valve margin, occluded by hymenes with short slits arranged on areolae margins (Fig. 27, arrow). Internally, valve face flat with silicified narrow rim running below the valve margin and following curvature of valve 

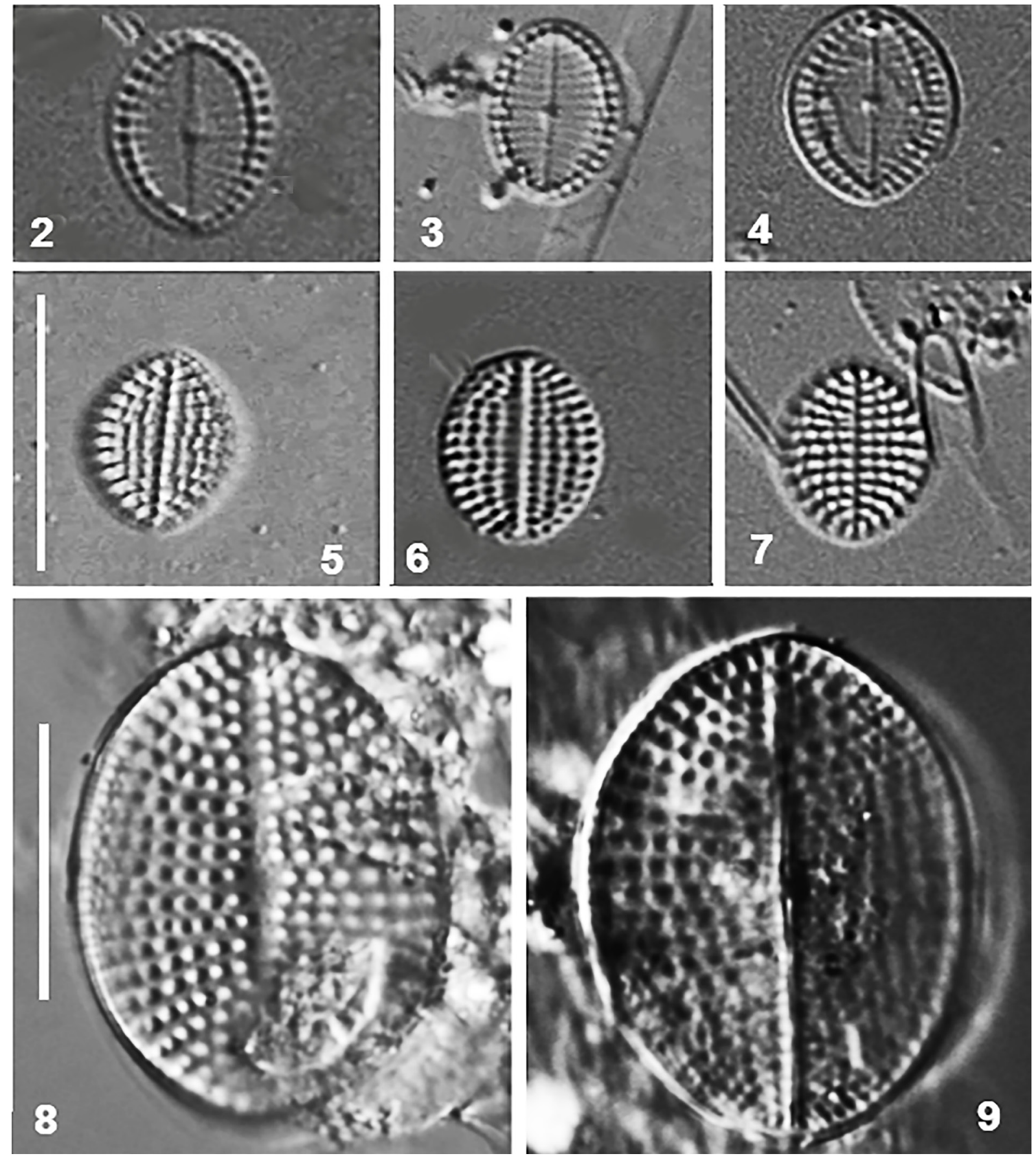

Figs 2-9. LM images. 2-4. RV of C. magnoareolata Al-Handal, Riaux-Gob., R.Jahn \& A.K.Wulff sp. nov., showing variations in size and valve outline (BGBM, slide B 40 0043104). 5-7. SV of C. magnoareolata sp. nov. (BGBM, slide B 40 0043104). 8-9. SV and RV of C. arenicola Ryznik (ANSP, slide no. 62634). Scale bars: $10 \mu \mathrm{m}$. 

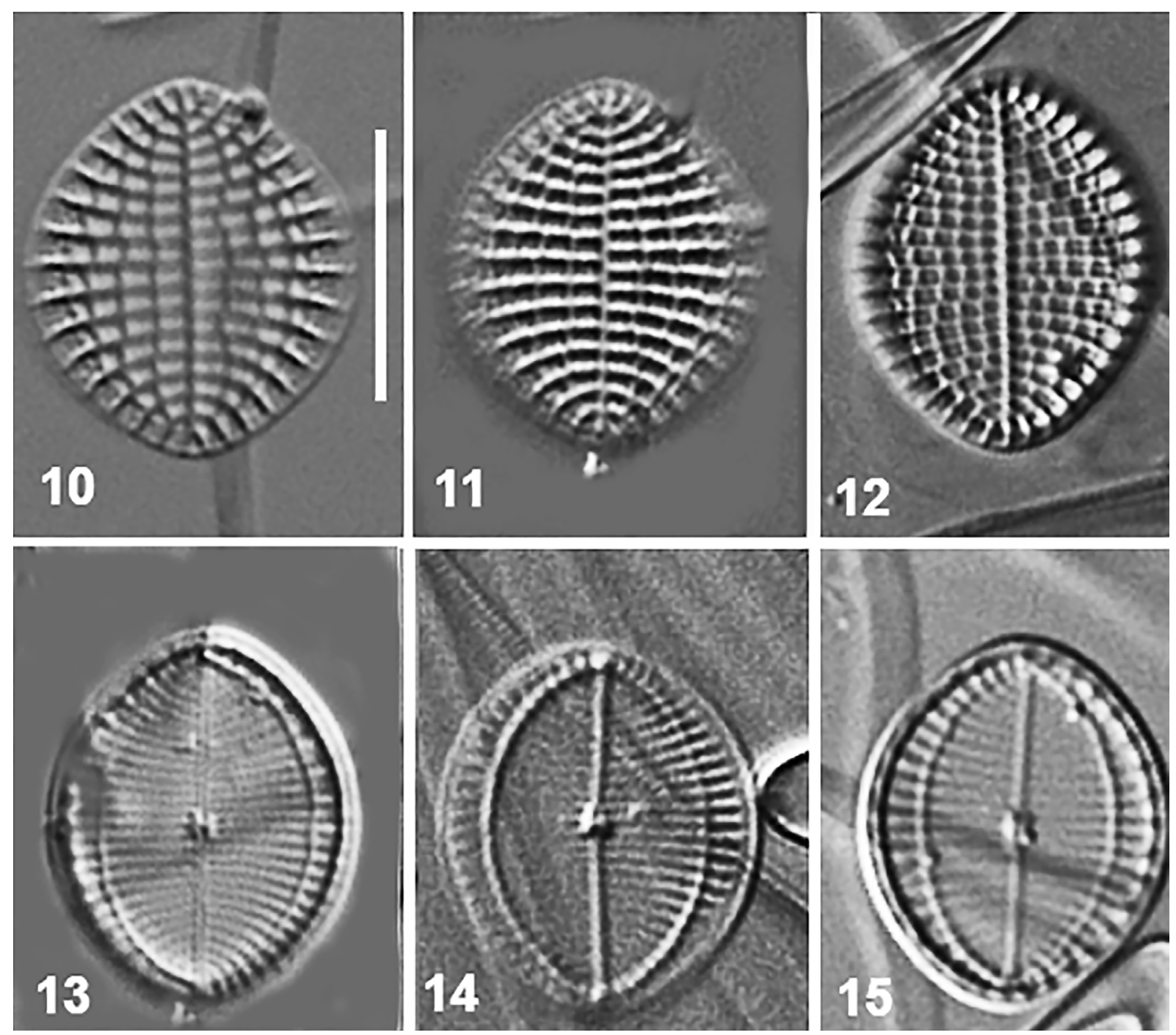

Figs 10-15. SEM images of Cocconeis vrangoensis Al-Handal \& Riaux-Gob. sp. nov. (BGBM, slide B 40 0043105). 10-12. SV. 13-15. Internal side of the RV, showing variations in valves size and outline. Scale bar: $10 \mu \mathrm{m}$. 

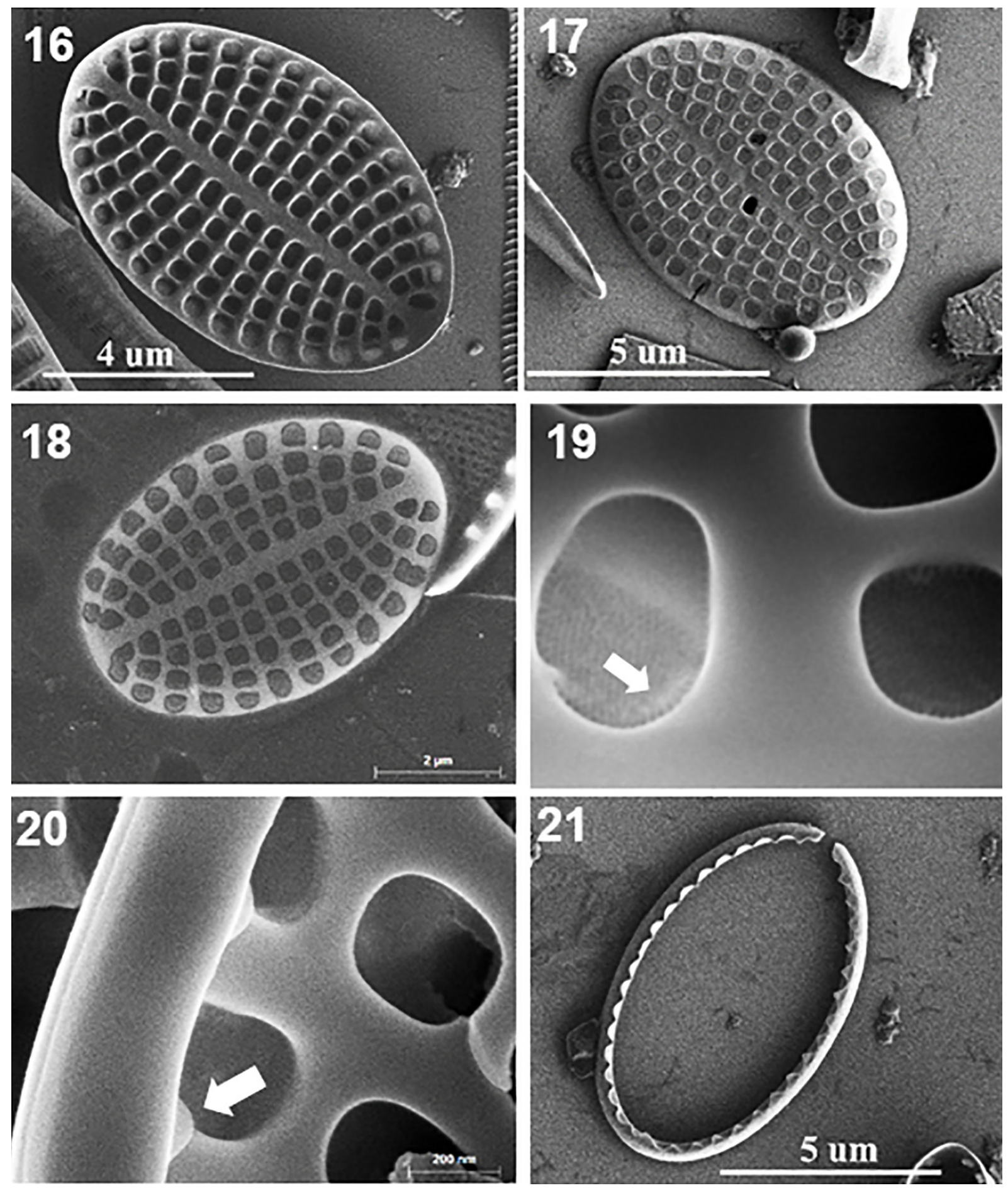

Figs 16-21. SEM images of C. magnoareolata Al-Handal, Riaux-Gob., R.Jahn \& A.K.Wulff sp. nov. (BGBM, slide B 40 0043104). 16. Internal view of the SV. 17-18. External view of the SV, showing subquadrangular areolae. 19. Hymenes of the SV arranged as slits on the margin of the areolae (arrows). 20. Abvalvar side of the SV valvocopulae with short fimbriae (arrow). 21. Open valvocopulae of the SV with numerous serrate fimbriae. 

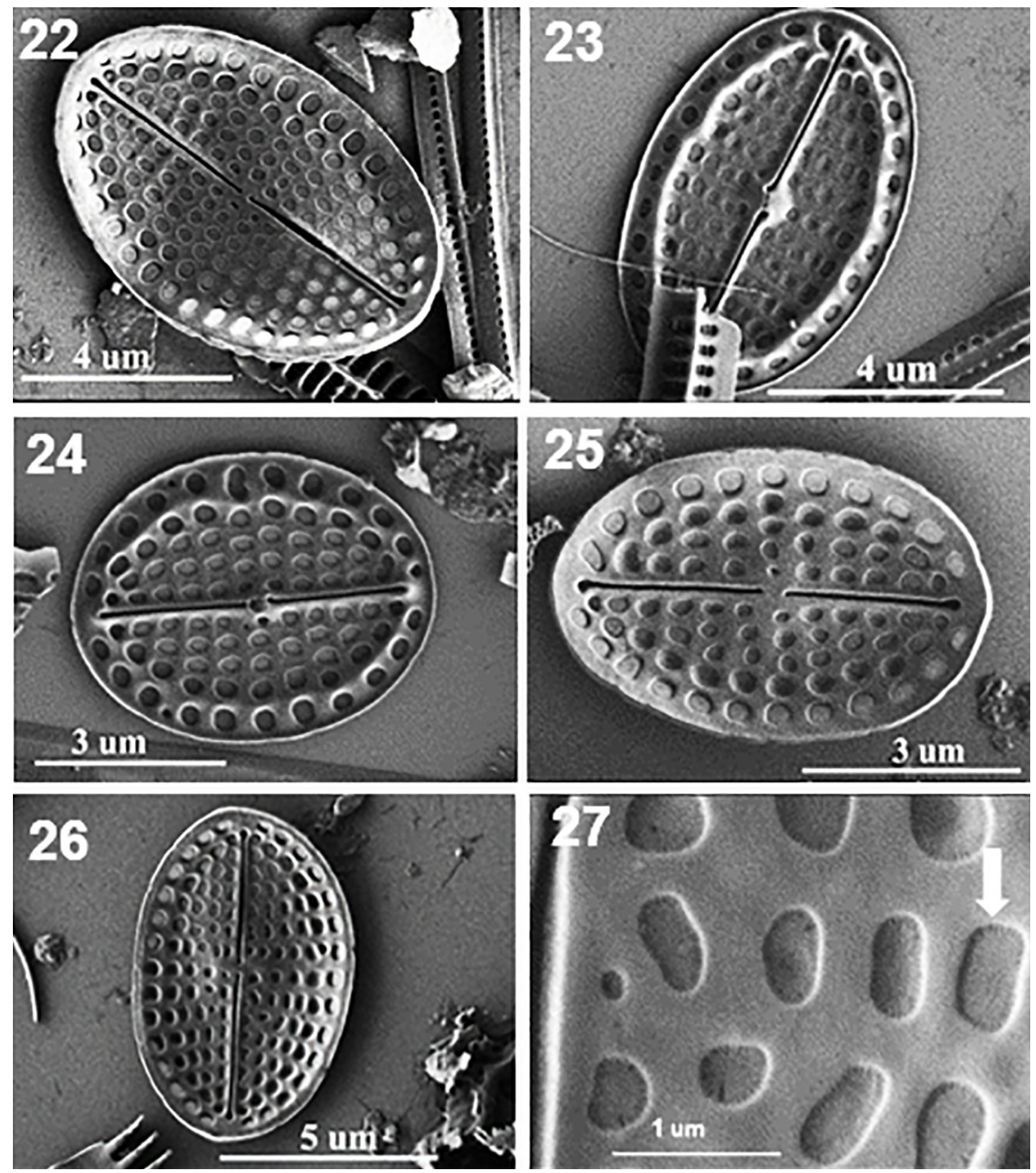

Figs 22-27. SEM images of $C$. magnoareolata Al-Handal, Riaux-Gob., R.Jahn \& A.K.Wulff sp. nov. (BGBM, slide B 40 0043104). 22, 25-26. External view of the outline and stria density of the RV. 23-24. Internal view of the RV exhibiting the slightly raised central area and the submarginal rim. 27. Enlarged part of the external face of raphe valve showing RV hymenes with a row of short marginal slits (arrow). 
outline, and encompassing a single longitudinal row of areolae (Figs 23, 25). Proximal raphe endings deflected in opposite directions, terminal raphe fissures ending in slightly raised and short helictoglossae (Fig. 23). Axial area very narrow, central area small, round, slightly elevated above valve face. Areolae orbicular or with irregular shape, increasing in size near the valve margin. Areolae near the valve margin are large and round. Valvocopulae not observed.

Cocconeis vrangoensis Al-Handal \& Riaux-Gob. sp. nov.

Figs 10-15, 28-45

\section{Differential diagnosis (LM)}

Valves broadly elliptic to slightly rhombic, with round apices. Apical axis $13-16 \mu \mathrm{m}(13.9 \pm 2.6)$, transapical axis $12-14 \mu \mathrm{m}(12.9 \pm 0.6, \mathrm{n}=72)$. Raphe straight, ending slightly before apices. Striae parallel in the middle, becoming radiate towards the apices, 24-26 in $10 \mu \mathrm{m}$ in the RV and 14-16 in $10 \mu \mathrm{m}$ in the SV. RV with a silica ridge close to the valve margin and following the curvature of the valve, wider near the center and narrower towards the apices.

\section{Etymology}

The specific epithet of the new species refers to the location where it was collected.

\section{Type material}

Holotype (Figs 11, 13: http://phycobank.org/1000795)

SWEDEN • Vrångö Island, eastern side of Vrångö Island; 57³4' N, $11^{\circ} 47^{\prime}$ E; Aug. 2016; A. Al-Handal s.n. leg.; intertidal zone, as epiphytic on Ulva intestinalis; BGBM, slide B 400043105.

Isotype

SWEDEN - Same data as for holotype; Department of Biological and Environmental Sciences, University of Gothenburg, slide V002.

\section{Description (SEM)}

\section{Sternum valve}

Convex on the external side, valve face flat to slightly depressed, with a wide mantle (Fig. 30). Axial area narrow and plain with no central area and terminating before the mantle (Fig. 30). Striae monoseriate becoming tri- to tetraseriate on the mantle. Virgae narrower than the striae and strongly raised on the internal valve face (Fig. 29). Areolae round to sub- quadrangular on both sides (Figs 29-30), sometime the septum between two adjacent areolae become very low or disappear and the areolae appear oblong with round corners (Figs 28-29). In SV internal side, the areolae are complex structure formed of 5-7 chambers (hymenate openings), one in the center and the others surrounding the central one (Fig. 32). The areolae on the mantle are long and composed of several small openings (Fig. 31). Each of these chambers is occluded by hymenes with linear perforations radially arranged (Figs 32-33). Valvocopula closed (Fig. 36), fimbriae thin, with finger-like extensions. On the advalvar side of the valvocopula, basal parts of the fimbriae are depressed and form grooves below the outer edge of the valvocopula (Fig. 35).

\section{Raphe valve}

Externally, RV slightly concave with marginal part of the mantle hyaline and void of areolae (Figs 3745, arrow). Raphe straight, proximal raphe endings simple and close to each other, terminal raphe endings slightly widening and terminate shortly before apices (Figs 37-45). Axial area very narrow, central area round and small. RV striae uniseriate except on the mantle where they become biseriate. Areolae round and occluded by hymenes with thin perforations radially arranged (Fig. 43). Internally, the RV face is slightly convex with very narrow hyaline area on the inner side of the mantle which is 

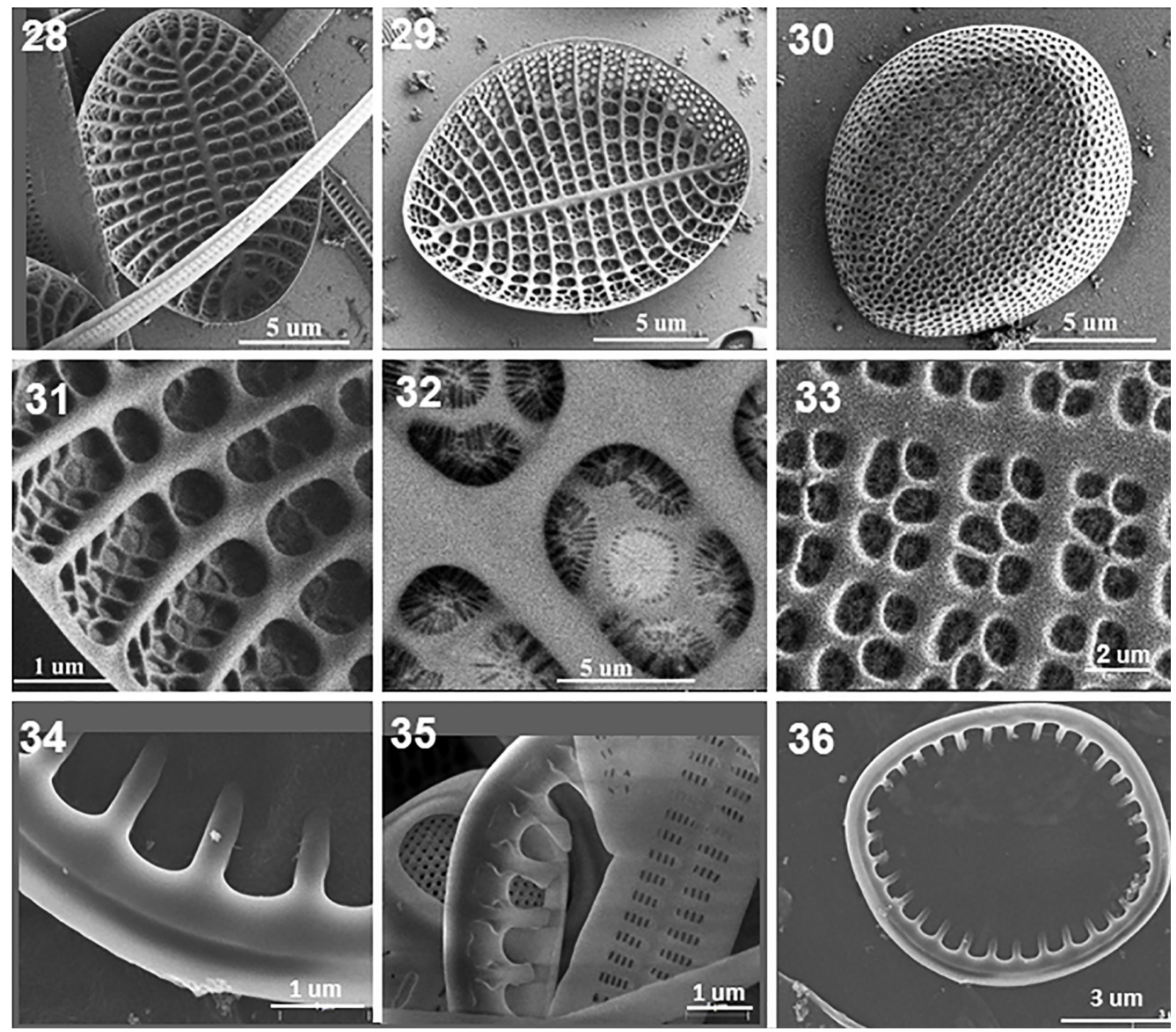

Figs 28-36. SEM images of $C$. vrangoensis Al-Handal \& Riaux-Gob. sp. nov. (BGBM, slide B 40 0043105). 28-29. Internal view of the SV. 30. External view of the SV. 31. Enlarged section of the marginal part of showing areola structure. 32. Areolae occluded by hymenes, internal side. 33. Radial arrangement of areolae, external side. 34. Advalvar side of the valvocopula showing shape of fimbria. 35. Abvalvar side of valvocopula. 36. Closed and strong valvocopula with fimbriae. 

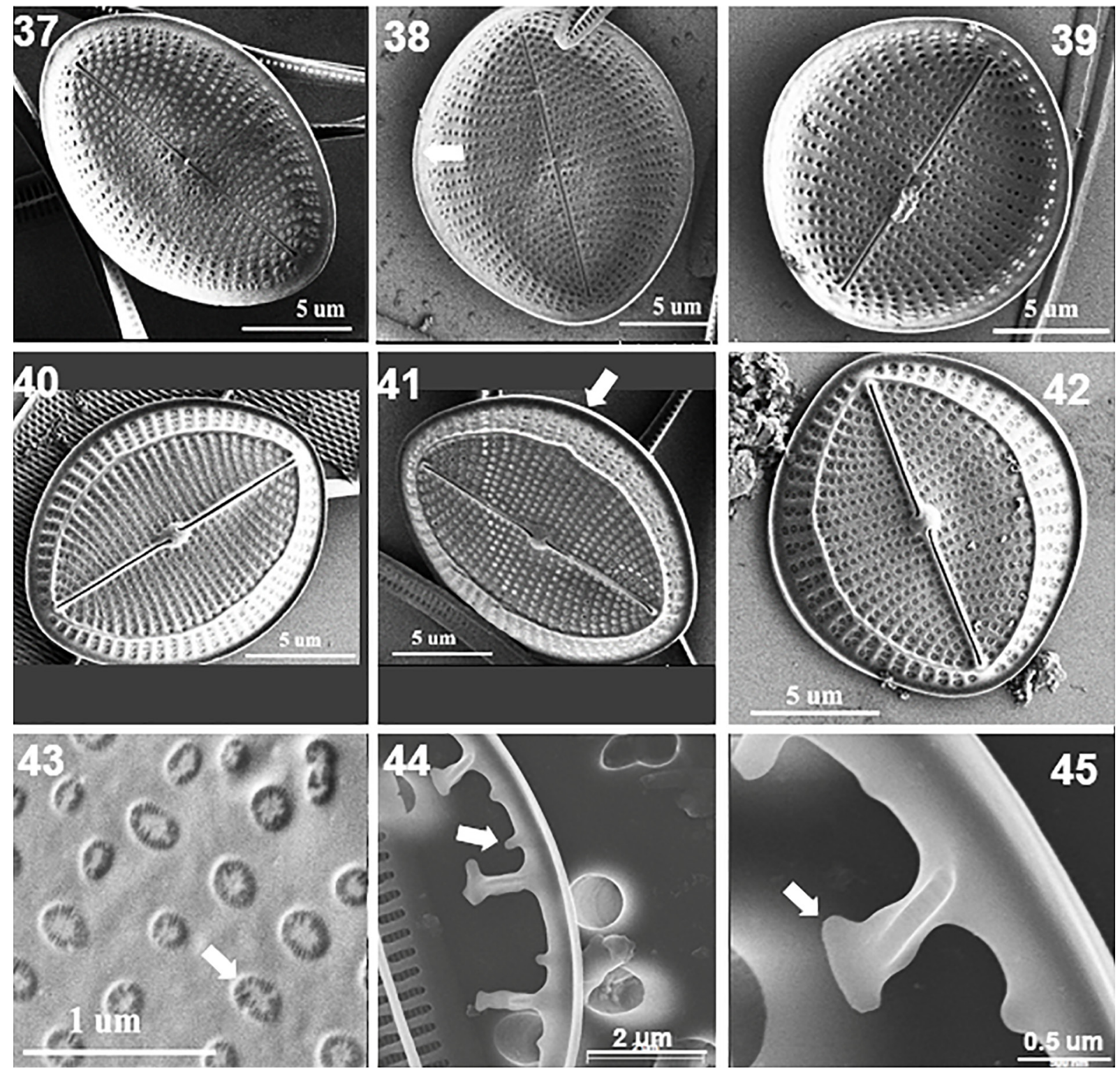

Figs 37-45. SEM images of $C$. vrangoensis Al-Handal \& Riaux-Gob. sp. nov. (BGBM, slide B 40 0043105). 37-39. External RV side showing uniseriate striae on valve face and bi- to triseriate striae on valve margin, as well as variation in valve outline, arrow on Fig. 36 points to the marginal hyaline area. 40-42. Internal RV side showing submarginal rim and marginal areolae, arrow on Fig. 41 points to the folded mantle. 43. Areolae with radiate marginal perforations of the hymens (arrow). 44. Abvalvar side of the valvocopulae showing shape of fimbriae, with intervalary short fimbriae (arrow). 45. Enlarged part of the abvalvar side of the valvocopula with an oblong papillae (arrow). 
strongly raised (Figs 40-42). Mantle margin folded inwards with a hyaline area void of areolae (Fig. 41, arrow). Raphe straight, proximal raphe endings deflected in opposite directions, terminal raphe endings terminating shortly before the apices and with weakly developed helictoglossae (Figs 40-42). Axial area very narrow, central area small, strongly silicified, round and raised above valve surface (Figs 40-42). Valvocopula with long and thin fimbriae ending by a hammer-like structure with an oblong papilla (Fig. 45, arrow). Between each pair of well-developed fimbriae there are short extensions that may be vestigial fimbriae (Fig. 44, arrow).

\section{Discussion}

\section{Comparison with Cocconeis arenicola}

Cocconeis magnoareolata sp. nov. with its large areolae may be compared to C. arenicola Ryznik, described from tidal flats in the Yaquina Estuary, USA, but the later differs by having larger valves $(22-27 \times 17-20 \mu \mathrm{m})$ and by its striae density, almost one third of that in our new species (7 vs 21-22 in $10 \mu \mathrm{m})$. Although C. arenicola was abundant in Yaquina Estuary, it has not been observed at any other geographic location. The type slide of this species (ANSP, slide no. 62634) has been examined. R.Z. Riznyk made seven small circles on the cover slip, and only two of these contain valves of C. arenicola. New images have been taken and illustrated here (Figs 8-9) to represent sternum and raphe valves. Sternum valve appears conforming to original description but the raphe valve does not seem to correspond to the description of the type by Riznyk (1973: pl. V, fig. 6). Striae density of both sternum and raphe valves described by the author is different from that observed in the type specimens. R.Z. Ryznyk gave seven striae in $10 \mu \mathrm{m}$ on both valves, while the specimens in the type slide show 9-9.8 and 12-16 in $10 \mu \mathrm{m}$ for sternum and raphe valves, respectively. Because of the very brief original description of this species, as well as of the varying of some features of the type specimens, an emended description is given below based on LM.

Cocconeis arenicola Riznyk emend. Al-Handal \& Riaux-Gob.

Figs 8-9

\section{Emended description}

Valve elliptical with broadly rounded apices, $24.6 \times 17.7-17.9 \mu \mathrm{m}$. SV with narrow and linear axial area (sternum) and small round central area. Striae radiate, equidistant, composed of large and round areolae, 9-9.8 in $10 \mu \mathrm{m}$. Areolae 16-18 in $10 \mu \mathrm{m}$. Short marginal striae of smaller areolae are present. RV with straight raphe, proximal raphe endings close to each other, distal endings terminate very shortly before apices. Striae radiate, equidistant with rounded areolae, 12-16 in $10 \mu \mathrm{m}$.

\section{Comparison with other allied taxa}

An entity that might look similar to the new taxon is C. nitens Edsbagge nom. inval., which also possesses large areolae according to its original description (Edsbagge 1968: 65), but differs in having larger valve size, elongate areolae on the sternum valve, coarser striae, a larger central area and the presence of a distinct marginal hyaline area on the RV. Cocconeis nitens nom. inval. was originally recorded from the west coast of Sweden and has been only reported once from the coasts of Mexico (López-Fuerte \& Siqueiros-Beltrones 2016). It is mentioned in the Diatoms New Taxon File website of the Academy of Natural Sciences (http://symbiont.ansp.org/dntf/details.php?id=011345) that the "type is not indicated" and the name is indicated as invalid. In his original description of $C$. nitens nom. inval., Edsbagge (1968: 65 ) did not assign any type slide number or deposition of any type material. According to Turland et al. (2018: Art. 40.1), C. nitens nom. inval. is not a valid name and it is not possible to validate it because the holotype and the type locality are not known, nor the date of collection. 
The ultrastructure of both $C$. arenicola and $C$. nitens has not been studied and therefore comparison with fine structure of C. magnoareolata sp. nov. is imposible. However, under LM, C. magnoareolata sp. nov. may have similarity with some taxa of the 'Cocconeis scutellum complex', but the fine structure of the areolae on both valves is rather different, e.g., being reticular on the SV (Fig. 18) and with short slit-like perforations located on areolae margin on the RV (Fig. 27). The SV valvocopula is also very different from that of the 'Cocconeis scutellum complex' (Fig. 21).

Morphologically, C. vrangoensis sp. nov. bears similarities to C. sagaraensis Hid.Suzuki and to some members of the 'Cocconeis scutellum complex', such as C. scutellum var. posidoniae M.De Stefano, D.Marino \& L.Mazzella. Cocconeis sagaraensis differs by having pointed valve apices, coarser striae on both valves, with 5-7 and 12-14 striae in $10 \mu \mathrm{m}$ on SV and RV respectively. In the internal face of the $\mathrm{RV}$ of $C$. vrangoensis sp. nov., the region between the hyaline rim and the valve margin has several rows of areolae (Figs 40-42), while in C. sagaraensis only one row of areolae is seen (Suzuki et al. 2005: figs 10,13$)$. The structure of the SV valvocopula is completely different between these two species. In C. sagaraensis, the SV valvocopula possesses complex thick structures, while the valvocopula in C. vrangoensis sp. nov. is thin with slender fimbria (Fig. 34).

Cocconeis vrangoensis sp. nov. is similar to C. scutellum var. posidoniae by having almost the same valve outline and striae density, but it can be distinguished by its different structure of areolae and valvocopulae. The SV areolae of C. scutellum var. posidoniae are different in shape and structure where it is composed of two radial bars and with hymenes that are radially arranged (described by De Stefano et al. (2000) as rotate hymenes) on the areolae margins. The SV and RV valvocopulae have fimbriae that are attached in their outer parts forming large pores while fimbriae of the SV valvocopulae of C. vrangoensis sp. nov. are plain slender extensions. The RV valvocopulae are hammerhead lobes alternating with short plain lobs in C. vrangoensis sp. nov. (Fig. 44), a feature that is not seen in any member of the 'Cocconeis scutellum complex'.

Under LM and with certain oblong specimens, C. vrangoensis sp. nov. may look slightly similar to C. stauroneiformis, particularly the SV (De Stephano et al. 2008: 237, figs 87-92). Stria density and complex areola structure, however, are different between these two species. The RV of $C$. stauroneiformis can be readily distinguished by the shape of its central area on the RV where it expands narrowly to the sides in a form of fascia reaching the valve margins.

Both C. magnoareolata sp. nov. and C. vrangoensis sp. nov. may appear as members of the 'Cocconeis scutellum complex' due to general morphological similarities. Cocconeis magnoareolata sp. nov., however, is far from this complex, based on its valve size (very small), its areola shape and size (subquadrangular and large), hymenes and SV valvocopulae structure (see above). Cocconeis vrangoensis sp. nov. can be separated from the 'Cocconeis scutellum complex' by having denser striae and different stria density on both valves, whereas most of the members of the 'Cocconeis scutellum complex' possesses almost similar stria densities on both valves except for C. scutellum var. posidoniae, and by some variations in areola and valvocopula structure.

The fourteen varieties of C. scutellum bear enough morphological similarities and led Hustedt (1933) to consider them as synonyms, a concept that also was followed by Hendey (1951). Nevertheless, the examination under SEM revealed structural differences that validate these varieties (e.g., De Stefano et al. 2008). The differences are mostly found in the structure and shape of the valvocopulae, such as the shape of fimbriae, whether the fimbriae have free or united ends, the presence and shape of the papillae (see discussion in Riaux-Gobin et al. 2013). According to Holmes et al. (1982), the particular shape or the structure of the valvocopulae is species-specific. The five lineages of the 'Cocconeis scutellum 
complex' proposed by Mizuno (1987), which were based on valve outline and stria density, need to be verified by molecular analysis.

\section{Small valve size range}

One of the noticeable characters of both new species is the small valve size range. Although a large number of specimens was measured ( 60 for $C$. magnoareolata sp. nov. and 72 for $C$. vrangoensis sp. nov.), yet valve size distribution was rather small. Valve length variation was only $2.5 \mu \mathrm{m}$ in C. magnoareolata $\mathrm{sp}$. nov. and $3 \mu \mathrm{m}$ in $C$. vrangoensis sp. nov. The distribution of both species is not yet known. They were only found on one macrophyte (Ulva intestinalis) although several other macrophytes and sediment samples from the same site were examined. The very small size of both species may not allow for wide variation in valve dimensions. There are, however, a number of environmental factors that affect cell size in diatoms. It has been demonstrated that small cell-sized diatom taxa with high surface area to volume ratio are more efficient in nutrient uptake with more ability to harvest light (Reynolds et al. 2002; Litchman et al. 2006).

\section{Acknowledgments}

We are grateful to Dr. Marina Potapova, of the Academy of Natural Sciences, Philadelphia, who examined type slide of C. arenicola and provided LM images. Thanks are due to Mr. Kim Govers and Miss Juliana Bettig of the Botanical Museum, Berlin for their help with SEM observations. The first author is grateful to professor Inger Wallentinus of the Department of Biological and Environmental Sciences, Gothenburg University for identifying the macrophytes. This research received support from the SYNTHESYS Project (http://www.synthesys.info/), financed by the European Community Research Infrastructure Action under the FP7 "Capacities" Program.

\section{References}

De Stefano M., Marino D. \& Mazzella L. 2000. Marine taxa of Cocconeis on leaves of Posidonia oceanica, including a new species and two new varieties. European Journal of Phycology 35: 225-242. https://doi.org/10.1080/09670260010001735831

De Stefano M., Romero O.E. \& Totti C. 2008. A comparative study of Cocconeis scutellum Ehrenberg and its varieties (Bacillariophyta). Botanica Marina 51: 506-536. https://doi.org/10.1515/BOT.2008.058

Edsbagge H. 1968. Zur Ökologie der marinen angehefteten Diatomeen. Botanica Gothoburgensia 6: 139.

Guiry M.D. \& Guiry G.M. 2018. AlgaeBase. National University of Ireland, Galway. Available from http://www.algaebase.org [accessed Feb. 2018].

Hendey N. I. 1951. Littoral diatoms of Chichester Harbour with special reference to fouling. Journal of the Royal Microscroscopic Society 71: 1-86. https://doi.org/10.1111/j.1365-2818.1951.tb01951.x

Holmes R.W., Crawford R.M. \& Round F.E. 1982. Variability in the structure of the genus Cocconeis Ehr. (Bacillariophyta) with special reference to the cingulum. Phycologia 21: 370-381. https://doi.org/10.2216/i0031-8884-21-3-370.1

Hustedt F. 1933. Die Kieselalgen Deutschlands, Osterreichs und der Schweiz unter Berucksichtigung der ubrigen Lander Europas sowie der angrenzenden Meeresgebiete. In: Rabenhorst L. \& Grunow A., Dr. L. Rabenhorst's Kryptogninen-Flora Lion Deutschland, Osterreich und der Schweiz 7, Teil $2(3,4)$ : 321-576. Akademische Verlagsgesellschaft, Leipzig.

Jahn R., Kusber W.H. \& Romero O.E. 2009. Cocconeis pediculus Ehrenberg and C. placentula Ehrenberg var. placentula (Bacillariophyta): Typification and taxonomy. Fottea 9: 275-288. 
Kristiansen T. \& Eyvind A. 2015. Water type quantification in the Skagerrak, the Kattegat and off the Jutland west coast. Oceanologia 57: 177-195. https://doi.org/10.1016/j.oceano.2014.11.002

Leskinen E., Alström-rapaport C. \& Pamilo P. 2004. Phylogeographical structure, distribution and genetic variation of the green algae Ulva intestinalis and U. compressa (Chlorophyta) in the Baltic Sea area. Molecular Ecology 13: 2257-2265. https://doi.org/10.1111/j.1365-294X.2004.02219.x

Litchman E., Klausmeier C.A., Miller J.R., Schofield O.M. \& Falkowski P.G. 2006. Multi-nutrient, multi-group model of present and future oceanic phytoplankton communities. Biogeosciences 3: 585606.

López-Fuerte F.O. \& Siqueiros-Beltrones D.A. 2016. A checklist of marine benthic diatoms (Bacillariophyta) from Mexico. Phytotaxa 282: 201-258. https://doi.org/10.11646/phytotaxa.283.3.1

Mizuno M. 1987. Morphological variation of the attached diatom Cocconeis scutellum var. scutellum (Bacillariophyceae). Journal of Phycology 23: 591-597. https://doi.org/10.1111/j.1529-8817.1987.tb04211.x

Reynolds C.S., Huszar V., Kruk C., Naselli-Flores L. \& Melo S. 2002. Towards a functional classification of the freshwater phytoplankton. Journal of Plankton Research 24: 417-428. https://doi.org/10.1093/plankt/24.5.417

Riaux-Gobin C. 1991. Diatomées d'une vasiére intertidale du Nord Finistère (Dourduff): genres Cocconeis, Campyloneis, Delphineis, Mastogloia et Raphoneis. Diatom Research 6: 125-135. https://doi.org/10.1080/0269249X.1991.9705151

Riaux-Gobin C.\& CompèreP. 1996. Observations sur le polymorphisme de Cocconeis californica Grunow, aux îles Kerguelen. Diatom Research 11: 89-103. https://doi.org/10.1080/0269249X.1996.9705367

Riaux-Gobin C., Romero E., Coste M. \& Galzin R. 2013. A new Cocconeis (Bacillariophyceae) from Moorea Island, Society Archipelago, South Pacific Ocean with distinctive valvocopula morphology and linking system. Botanica Marina 56: 339-356. https://doi.org/10.1515/bot-2012-0162

Riaux-Gobin C., Compère P. \& Jordan R.W. 2015. Cocconeis Ehrenberg assemblage (Bacillariophyceae) from Napuka Atoll (Tuamotu Archipelago, South Pacific) with description of two new taxa. Diatom Research 30: 175-196. https://doi.org/10.1080/0269249X.2015.1021839

Riznyk R.Z. 1973. Interstitial diatoms from two tidal flats in Yaquina Estuary, Oregon, USA. Botanica Marina 16: 113-138. https://doi.org/10.1515/botm.1973.16.3.113

Romero O.E. \& Navarro J.N. 1999. Two marine species of Cocconeis Ehrenberg (Bacillariophyceae): C. pseudomarginata Gregory and C. caribensis sp. nov. Botanica Marina 42: 581-592. https://doi.org/10.1515/BOT.1999.065

Sar E.A., Romero O. \& Sunesen I. 2003. Cocconeis Ehrenberg and Psammococconeis Garcia (Bacillariophyta) from the Gulf of San Matia, Patagonia, Argentina. Diatom Research 18: 79-106. https://doi.org/10.1080/0269249X.2003.9705575

Suzuki H., Nagumo T. \& Tanaka J. 2001. Morphology of the marine epiphytic diatom Cocconeis convexa Giffen (Bacillariophyceae). Diatom 17: 59-68. https://doi.org/10.11464/diatom1985.17.0_59

Suzuki H., Nagumo T. \& Tanaka J. 2005. A new marine diatom Cocconeis sagaraensis Hid. Suzuki (Bacillariophyceae) from Japan. Journal of Japan Botany 80: 176-185.

Turland N.J., Wiersema J.H., Barrie F.R., Greuter W., Hawksworth D.L., Herendeen P.S., Knapp S., Kusber W.-H., Li D.-Z., Marhold K., May T.W., McNeill J., Monro A.M., Prado J., Price M.J. \& Smith G.F. (eds.) 2018. International Code of Nomenclature for Algae, Fungi, and Plants (Shenzhen Code) 
adopted by the Nineteenth International Botanical Congress Shenzhen, China, July 2017. [Regnum Vegetabile 159.] Koeltz Botanical Books, Glashütten. https://doi.org/10.12705/Code.2018

VanLandingham S.L. 1979. Catalogue of the Fossil and Recent Genera and Species of Diatoms and their Synonyms 7: 4242-4654. J. Cramer, Vaduz.

Manuscript received: 28 February 2018

Manuscript accepted: 5 December 2018

Published on: 12 February 2019

Topic editor: Frederik Leliaert, Ph.D.

Desk editor: Alejandro Quintanar

Printed versions of all papers are also deposited in the libraries of the institutes that are members of the EJT consortium: Muséum national d'Histoire naturelle, Paris, France; Meise Botanic Garden, Belgium; Royal Museum for Central Africa, Tervuren, Belgium; Royal Belgian Institute of Natural Sciences, Brussels, Belgium; Natural History Museum of Denmark, Copenhagen, Denmark; Naturalis Biodiversity Center, Leiden, the Netherlands; Museo Nacional de Ciencias Naturales-CSIC, Madrid, Spain; Real Jardín Botánico de Madrid CSIC, Madrid, Spain; Zoological Research Museum Alexander Koenig, Bonn, Germany. 